PERM JOURNAL OF PETROLEUM AND MINING ENGINEERING ВЕСТНИК ПНИПУ. ГЕОЛОГИЯ. НЕФТЕГАЗОВОЕ И ГОРНОЕ ДЕЛО

ISSN 2224-9923

Volume / Toм 16 №4 2017

http://vestnik-pstu.ru/geo/

УДК 622:331.4

Article / Статья

(C) PNRPU / ПНИПУ, 2017

\title{
ANALYTICAL REVIEW OF WORKING CONDITIONS OF UNDERGROUND PERSONNEL IN THE OIL MINES OF THE YAREGSKOE FIELD
}

\author{
Taras V. Grunskoy, Vladimir P. Perkhutkin, Aleksandr G. Berdnik
}

Ukhta state technical university (13 Pervomayskaya st., Ukhta, Komi Republic, 169300, Russian Federation)

\section{АНАЛИТИЧЕСКИЙ ОБЗОР УСЛОВИЙ ТРУДА ПОДЗЕМНОГО ПЕРСОНАЛА НЕФТЯНЫХ ШАХТ ЯРЕГСКОГО МЕСТОРОЖДЕНИЯ}

\section{Т.В. Грунской, В.П. Перхуткин, А.Г. Бердник}

Ухтинский государственный технический университет (169300, Россия, Республика Коми, г. Ухта, ул. Первомайская, 13)

Received / Получена: 31.08.2017. Accepted / Принята: 11.10.2017. Published / Опубликована: 01.12.2017

\section{Key words:}

oil mine, special assessment of working conditions, class of working conditions, Yaregskoe field, underground personnel, thermoshaft method, workplace, probability of factor impact.

Ключевые слова нефтешахта, специальная оценка условий труда, класс условий труда, Ярегское месторождение, подземный персонал, термошахтный способ, рабочее место, вероятность воздействия фактора.

\begin{abstract}
At the present stage of production enhancement it is impossible to create absolutely safe working conditions in the oil production mines of the Yaregskoe field, but ensuring acceptable working conditions in the workplace remains one of the most important tasks in the field of labor protection. Yaregskoe is unique oil field in terms of the shaft method of heavy oil mining. An oil shaft is rather a deviation from the general ideas about the mining industry of Russia and the world. The main idea of the thermoshaft method is a decrease in viscosity and increase in oil mobility due to the heating of a formation by coolant injection. The technology used to extract heavy oil has created special working conditions. The majority of workplaces in oil mines correspond to the $3^{\text {tr }}$ class of working conditions (harmful), degrees 3.1-3.3, where the maximum permissible levels of exposure to harmful factors are exceeded in comparison with permissible values. Harmful working conditions entail a consistently high level of occupational disease. The variety of negative factors and possibility of their combined effects on the body with various combinations of the labor process determine the need for an integrated approach to assess the combined effects of negative factors. Today, the assessment of working conditions is carried out in accordance with the Federal Law of the Russian Federation No. 426-FL "On a special assessment of working conditions" and Order No. 33n of the Ministry of Labor of Russia "On approving the methodology for conducting a special assessment of working condition classifier of harmful and (or) dangerous production factors, the form of a report on the special assessment of working conditions and instructions its filling". In a special assessment of working conditions the overall result is affected only by factors beginning with grades 3 and 4 of working conditions. The combined effect of production and labor process factors is represented only by a qualitative assessment.

The analysis performed allowed to rank the probability of the impact of factors of a certain class of working conditions on workers of the Yaregskoe oil mines by structural subdivisions.

To assess how labor conditions conform normative labor requirements and a degree of impact of deviations from normal values on To assess how labor conditions conform normative labor requirements and a degree of impact of deviations from normal values on
human body a special point system (usually a six-point system) is used. There is a calculation of professional risks for the underground human body a special point system (usually a six-point system) is used. There is a calculatic
staff of the Yaregskoe oil mine made based on the "Point assessment of professional risk".

staff of the Yaregskoe oil mine made based on the "Point assessment of professional risk". Assessment of occupational diseases shows a high risk of obtaining occupational diseases for a group of underground workers of the
Yaregskoe oil mine. There is a special risk for workers at mining and oil production sites. The risk is represented in three parameters such as increased noise, vibration and physical overload. An underground miner and road worker are the safest jobs.
\end{abstract}

На современном этапе интенсификащии производства создание абсолютно безопасных условий труда на нефтедобываюших шахтах Ярегского месторождения невозможно, но обеспечение допустимых условий труда на рабочих местах остается одной из шахтах Ярегского месторождения невозможно, но обеспечение допустимых условий труда на рабочих местах остается одной из важнейших задач в области охраны труда. Ярегское нефтяное месторождение уникально в шахтном методе добычи тяжелой нефти. Нефтешахта, скорее, отступление из общепринятых представлений о добывающей шахтной промышленности России и мира. Основой термошахтног метода является снижение вязкости и повышение подвижности нефти за счет разогрева

Помощью закачки теплоносителя. Используемая технология добычи тяжелой нефти сформировала особые условия труда. В нефтешахтах большинство рабочих мест соответствуют 3-му классу условий труда (вредные), степени 3.1-3.3, при которых
наблюдается превышение предельно допустимых уровней воздействия вредных факторов по сравнению с допустимыми наблюдается превышение предельно допустимых уровней воздействия вредных факторов по сравнению с допустимыми значениями. Вредные условия труда влекут стабильно высокий уровень профессиональной заболеваемости. Многообразие
воздействующих негативных факторов и возможность их комбинированного воздействия на организм при различных комбинациях трудового процесса определяют необходимость комплексного подхода к оценке комбинированного воздействия негативных факторов.

В настоящее время оценка условий труда выполняется в соответствии с Ф3 РФ № 426-Ф3 «О специальной оценке условий труда» и приказом Минтруда России № 33н «Об утверждении методики проведения специальной оценки условий труда, классификатора вредных и (или) опасных производственных факторов, формы отчета о проведении специальной оценки условий руда и инструкции по ее заполнению». При проведении специальной оценки условий труда на общий результат влияют только факторы, начиная с 3-го и 4-го класса условий труда. Комбинированное воздействие производственньх и факторов трудового процесса представлено лишь качественной оценкой.

Выполненный анализ позволил провести ранжирование вероятности воздействия факторов определенного класса условий

Выполненныи анализ позволил провести ранжирование вероятности воздействия факторов определенного класса условий
Длда на работников ярегских нефтешахт по структурным подразделения. ДЛя оценки степени соответствия состояния условий труда нормативным требованиям и степени влияния на организм человека отклонений от нормативных значений факторов условий труда используется система специальных баллов (обычно
шестибалльная система). На основании «Балльной оценки профессионального риска» был произведен расчет шестибалльная система). На основании «Балльной оценки професси

Пценка профзаболеваний показывает высокий риск получения профзаболевания для группы подземных работников ярегских Оценка профзаболеваний показывает высокий риск получения профзаболевания для группы подземных работников ярегских наблюдается высокий уровень риска по трем параметрам: повышенный уровень шума, вибрации, физические перегрузки. Наиболее безопасными рабочими местами являются горнорабочий подземный и дорожно-путевой рабочий.

Taras V. Grunskoy - Senior Lecturer at the Department of Industrial Safety and Environmental Protection (tel.: +007 8216774513 , e-mail: uxtacity@yandex.ru). The contact person for correspondence.

Vladimir P. Perkhutkin - PhD in Engineering, Associate Professor at the Department of Industrial Safety and Environmental Protection (tel.: +007 8216 774 513, e-mail: uxtacity@yandex.ru). Aleksandr G. Berdnik - PhD in Engineering, Associate Professor at the Department of Industrial Safety and Environmental Protection (tel.: +007 8216 774 513, e-mail: zav pbioos@ugtu.net).

Грунской Тарас Валерьевич - старший преподаватель кафедры промышленной безопасности и охраны окружающей среды (тел.: +007 216774513 , e-mail: uxtacity@yandex.ru). Контактное лицо для переписки.

Перхуткин Владимир Павлович - кандидат технических наук, доцент кафедры промышленной безопасности и охраны окружающей среды (тел.: +007 216774513 , e-mail: uxtacity@yandex.ru).

Бердник Александр Григорьевич - кандидат технических наук, доцент кафедры промышленной безопасности и охраны окружающей среды (тел.: +007 216774513 , e-mail: zav_pbioos@ugtu.net). 


\section{Introduction}

The Yareganeft oil mine management department (OMMD) includes three oil-producing mines. There are 436 positions that were specially estimated for working conditions (SEWC) from 2014 to 2016. Based on results of SEWC a list of recommended measures to improve working conditions at 309 workplaces was developed. Working conditions of the personnel of various structural divisions can be understand through the analysis of protocols, maps and summary statements of the SEWC of the Yarega oil mines [1-6].

Levels of hazardous and harmful production factors are determined on the basis of instrumental measurements that were carried out in accordance with established methods with efficient and effective collective and individual protection facilities. The time of exposure to hazardous and harmful production factors was determined on the basis of the timekeeping carried out and work on duty magazine [7-9].

In order to ensure completeness and reliability of accounting for workplaces, the classification characteristics were used that are as follows:

- stationary or non-stationary - by the nature of the technical equipment and location of workplaces in the space;

- individual or collective - by the number of personnel employed in the workplace.

\section{Analytical review of working conditions of underground personnel}

There are 77 workplaces with acceptable working conditions and 359 workplaces with harmful and dangerous conditions.

In accordance with the classifier of harmful and (or) dangerous production factors controlled parameters are chemical, biological, physical (aerosols, noise, infrasound, ultrasound, general and local vibration, non-ionizing and ionizing radiation, microclimate, illumination), severity and tension work processes $[10,11]$.

Identified workplaces with harmful and dangerous factors based on the measurement and evaluation of SEWC are given in the Table 1.

Determination of the class of working conditions of workplaces is made in accordance with the "Classifier of harmful and (or) dangerous production factors", on the basis of which the working conditions are divided into 4 classes such as optimal, permissible, harmful and dangerous $[12,13]$.
Table 1

Harmful and dangerous factors defined on the basis of measurements and assessments of SEWC

\begin{tabular}{|l|c|}
\hline \multicolumn{1}{|c|}{$\begin{array}{c}\text { Name of harmful and (or) dangerous } \\
\text { production factor }\end{array}$} & $\begin{array}{c}\text { Number } \\
\text { of workplaces }\end{array}$ \\
\hline Chemical & 96 \\
\hline $\begin{array}{l}\text { Aerosols of predominantly fibrogenic } \\
\text { action (APFA) }\end{array}$ & 77 \\
\hline Noise & 341 \\
\hline Vibration total & 4 \\
\hline Vibration local & 59 \\
\hline Microclimate & 78 \\
\hline Labor severity & 179 \\
\hline
\end{tabular}

The classifier of harmful and (or) dangerous production factors allows to assess the conditions and nature of work in the workplace in order to:

- establish professional risk levels for development of preventive measures and justification of social protection measures for employees;

- compare employee's state of health with his working conditions;

- set priorities for implementation of health measures and assessing their effectiveness.

The Fig. 1 presents mean results of SEWC performed on oil mines of the Yaregskoe field.

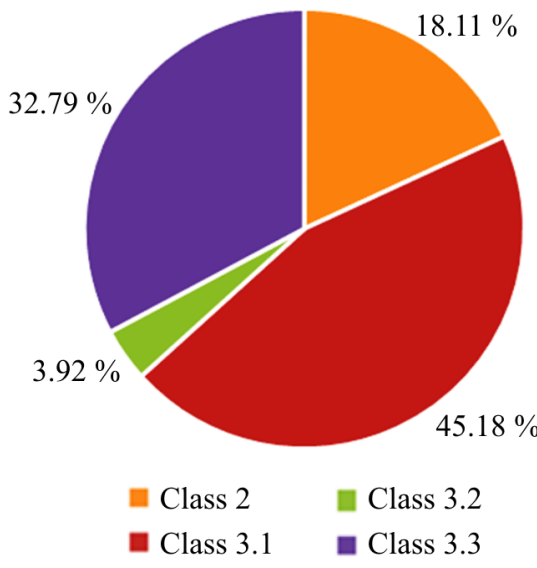

Fig. 1. Distribution of workplaces by classes of working conditions

The majority of workplaces at the Yaregskoe oil mines belong to the class with harmful working conditions $(82 \%)$, i.e. workers may experience occupational diseases. Subclasses 3.1 and 3.3 have 45 and $33 \%$, respectively, corresponding to a very high degree of occupational risk [14].

Harmful working conditions at workplaces of the personnel of oil mines are caused by both physical factors (noise, vibration, microclimate and APFA) and factors of the labor process (labor severity) and chemical factors which is a characteristic of oil production company. 
Share distribution of harmful and hazardous production factors for the Yaregskoe oil mines is given in the Fig. 2.

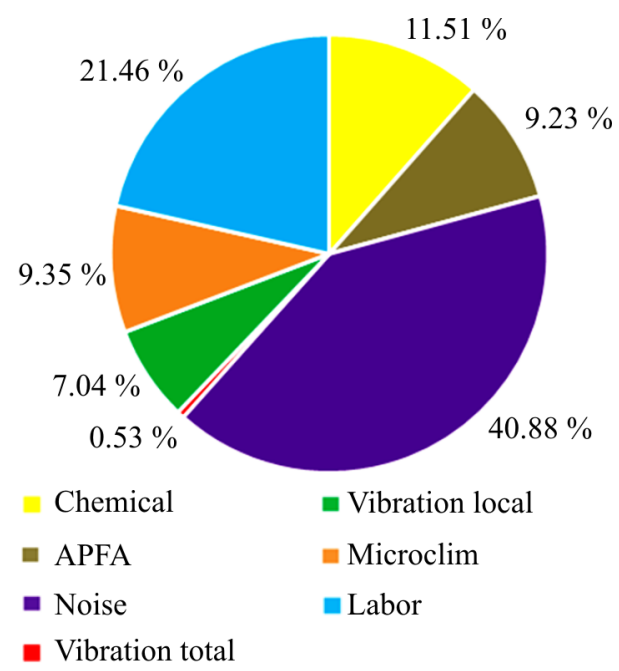

Fig. 2. Share distribution of harmful and hazardous production factors

There is in the oil industry a large part of the production personnel works under the influence of increased noise levels (40.88\%), labor severity $(21.46 \%)$, chemical factors $(11.51 \%)$, humidity and temperature $(9.35 \%)$, dustiness $(9.23 \%)$, local vibration $(7.04 \%)$ and total vibration $(0.53 \%)$. There are one or several harmful factors, levels of which exceed the established norms at workplaces of underground workers of the basic professions. Harmful working conditions attract a consistently high level of occupational diseases $[15,16]$.

Experience suggests that in order to obtain a reliable estimate of working conditions, a SEWC has to be carried out, in maps where levels of harmful and dangerous factors are clearly established at each workplace and for certain technological processes and operations.

High levels of severity of the labor process (classes 3.1-3.2) are noted in persons of working specialties and middle-level specialists. High indicators in the first group are caused first of all by the fact that they lift and move over-standard masses of weight by hands, forced slopes of the hull at an angle of more than $30^{\circ}$ and displacement in space. In the second group that is caused by the need to use in the process of work a large number of portable instrumentation, which are used directly by the employee, and movement in space, due to the technological process. High indicators of work severity of the process are a prerequisite for development of musculoskeletal system diseases [17].
Total and local vibrations, noise, APFA, microclimate and chemical factor at worksplaces of the underground group of oil mine workers belong mainly to classes $3.1,3.2$ and 3.3, i.e. can cause industry-related diseases. However, their combined effect with higher indicators of physical factors can lead to development of occupational diseases of various etiologies [11].

By the priority occupational diseases of the oil industry thay are as follows: vibro-disease, chronic loins-sacral radiculopathy, chronic neurosensory hearing loss and the only case of reflex myotonic syndrome [18].

According to results of the SEWC, intensity of the labor process is absent in all work places of the Yaregskoe oil refineries. Indicators of the intensity of the labor process are directly related to the specific conditions of underground labor activity, in particular the activities of oil production operators, mining machine drivers, whose work involves knowledge of instructions for both labor protection and industrial safety, and for production and mining operations, in addition, high emotional stress during the operation and maintenance of process equipment.

However, when examining workplaces, difficulties arise in assessing the intensity of the work of the underground personnel in oil mines related to the absence of an express methodology for assessing the intensity of the labor process in the SEWC, which allows shortening the time for assessing workplaces by working conditions [19].

It is proposed to develop a methodology for assessing the indicators of the labor process, which should take into account the world experience in assessing the indicators of the intensity of the labor process and base on checklists and questionnaires. Such an approach is a generally accepted means of data collection for persons involved in organizational planning, performance evaluation, safety management and health protection, designing interaction between a worker and machine as well as working conditions [20,21].

The evaluation of the indicators of tension is obtained as a result of the study of a workplace, technological process, operations and interviewing of the employee, comparison of estimates obtained, detection of the percentage of discrepancies and comparison of the percentage of discrepancies with its permissible level.

The methodology proposed will reduce the time for assessing the severity and tension of the 
work of underground oil mines personnel, while ensuring comparability with results obtained during SEWC.

A summary list of results of SEWC is presented in Table 2. Workplaces of the management department (MD), preparation site, oil shipment and bottom water injection (SEWC and BWI), steam-water-heat workshops (SWHW), production support site (PSS), wood processing site (WPS), mechanization and production automation sites (MS and PAS) are located on the surface and intended for persons involved in the management and technical support of the work of the oil mine underground personnel.

Table 2

Summary list of SEWC results

\begin{tabular}{|c|c|c|c|c|c|c|c|c|c|}
\hline \multirow{3}{*}{ Name } & \multicolumn{2}{|c|}{$\begin{array}{l}\text { Number of workplaces } \\
\text { and number of employees }\end{array}$} & \multicolumn{7}{|c|}{$\begin{array}{l}\text { Number of workplaces and number of employees work } \\
\text { on them by classes (subclasses) of working conditions }\end{array}$} \\
\hline & \multirow{2}{*}{ total } & \multirow{2}{*}{$\begin{array}{l}\text { where SEWC } \\
\text { is carried }\end{array}$} & \multirow{2}{*}{ class 1} & \multirow{2}{*}{ class 2} & \multicolumn{4}{|c|}{ class 3} & \multirow{2}{*}{ class 4} \\
\hline & & & & & 3.1 & 3.2 & 3.3 & 3.4 & \\
\hline Employees & 436 & 436 & 0 & 79 & 197 & 17 & 143 & 0 & 0 \\
\hline Employees in the workplace, people. & 1443 & 1443 & 0 & 121 & 592 & 91 & 639 & 0 & 0 \\
\hline Manadgement department & 40 & 40 & 0 & 40 & 0 & 0 & 0 & 0 & 0 \\
\hline Oil mine no. 1 & 113 & 113 & 0 & 3 & 61 & 0 & 49 & 0 & 0 \\
\hline Oil mine no. 2 & 107 & 107 & 0 & 3 & 58 & 0 & 46 & 0 & 0 \\
\hline Oil mine no. 3 & 111 & 111 & 0 & 5 & 57 & 0 & 49 & 0 & 0 \\
\hline Oil production site & 3 & 3 & 0 & 2 & 1 & 0 & 0 & 0 & 0 \\
\hline SEWC and BWI & 4 & 4 & 0 & 0 & 3 & 1 & 0 & 0 & 0 \\
\hline WPS & 2 & 2 & 0 & 0 & 1 & 1 & 0 & 0 & 0 \\
\hline SWHW & 47 & 47 & 0 & 20 & 13 & 14 & 0 & 0 & 0 \\
\hline PSS & 4 & 4 & 0 & 4 & 0 & 0 & 0 & 0 & 0 \\
\hline MS and PAS & 5 & 5 & 0 & 2 & 3 & 0 & 0 & 0 & 0 \\
\hline
\end{tabular}

The most harmful working conditions are in oil mines at workplaces of the underground group of workers which is only considered. The group of management department is considered as a reference one, whose class of working conditions is permissible.

The analysis of protocols of the special evaluation, maps and summary statements of the working conditions of the oil mine will allow developing a rating ranking of the negative factors in priority to reduce their negative impact on the underground personnel of Yaregskoe oil mines.

\section{Assessment of the probability of exposure factors of a certain class working conditions on employees}

Based on an analytical review, the probabilities of the impact of factors of a certain class of working conditions on the employees of the management department and three oil mines, as well as various structural subdivisions of the oil mines of the Yaregskoe field were calculated (Fig. 3a-d) [22].

Distribution of probability of the impact of factors of a certain class of working conditions on employees of the Yaregskoe oil mines indicates that the structure of harmful and dangerous factors is similar and almost the same for all three oil mines.
An analysis of the distribution allowed to determine the structural subdivisions for which the most likely impacts are the factors of a certain hazard class and hazard of working conditions (oil production site, site of mine excavation and expansion and site of repair and remedial works and intermine transportation [23].

A generalized calculation of the probability of effects of factors of a certain class of working conditions on employees of structural subdivisions of oil mines of the Yaregskoe field is shown in Fig. $3 e$.

As a result of assessment of significance of harmful and dangerous production factors of a physical group, it is established that their identification in workplaces is possible for all hazards except APFA, whose contribution to the total number of occupational diseases for oil mine employees is $2 \%$. At the same type of workplace the variation of harmful factors is within the limits of classes 2-3.1. Such a factor, as a dust effect, slightly affects the occurrence of occupational disease $[24,25]$.

At the same type of workplace the amount of dust in the air can be within the limits of classes 2-3.3. 

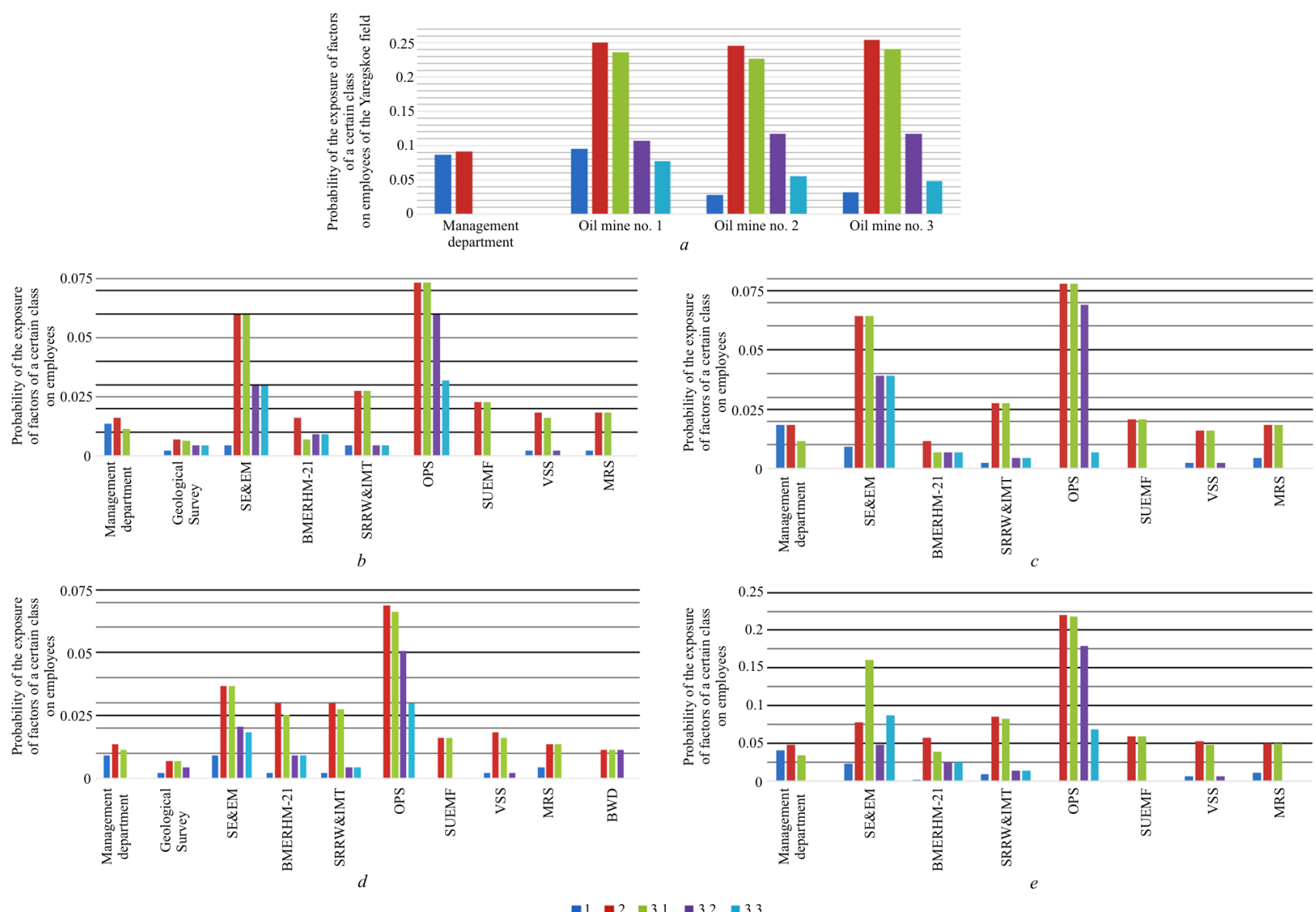

Fig. 3. Distribution of the probability of the exposure of factors of a certain class on working conditions on employees: $a$ - OMMD Yareganeft; $b$ - structural subdivisions of the oil mine No. 1; $c$-structural subdivisions of the oil mine No. 2; $d$-structural subdivisions of the oil min No. $3 ; e$ - structural subdivisions of oil mines; SME\&E - site of mine excavation and expansion; OPS - oil production site; SRRW\&IMT - site of repair and remedial works and intermine transportation; BMERHM-21 - brigade on mining of excavations by road header machine KP-21; SUEMF - site of underground electromechanical facilities; VSS - ventilation and safety site; MRS - mine raise site; BWD - brigade on well drilling

\section{Assessment of occupational risks of underground personnel}

The object of the study is assessment of professional risks of underground personnel of the Yaregskoe oil mines. Activities of the personnel of oil mines are characterized by a combination of factors in the production environment and labor process that directly affect workers.

An analytical review of occupational pathology in companies extracting oil by mining method over the past 16 years with the given statistical indicators and structure of occupational deseades is shown in the Fig. 4 [26].

The level of occupational diseases in the production oil mine industry remains stably high. The average number of underground personnel for 16 years is 170 people, the total number of cases is 122 .

Analysis of statistical data for oil mine production showed that the production personnel works using vibrating tool $(75.6 \%)$, heavy physical labor was detected in $61.2 \%$, noise effect in $84.7 \%$. Comparison of harmful and dangerous production factors causing occupational diseases of personnel in the coal and oil mine production industry of the Komi Republic for 2000-2016 shows a different etiology of occupational pathologies.

The structure of occupational deseases by categories of personnel is shown in the Fig. 5.

The main causes of occupational diseases in oil mines are vibration, heavy physical labor, noise, unfavorable microclimate.

All cases of occupational diseases are recorded at the site of mine excavation and expansion. The greatest number of cases was recorded in miners and timbermans, which is associated with simultaneous exposure in the main labor operations of harmful factors that cause occupational diseases $[27,28]$. 


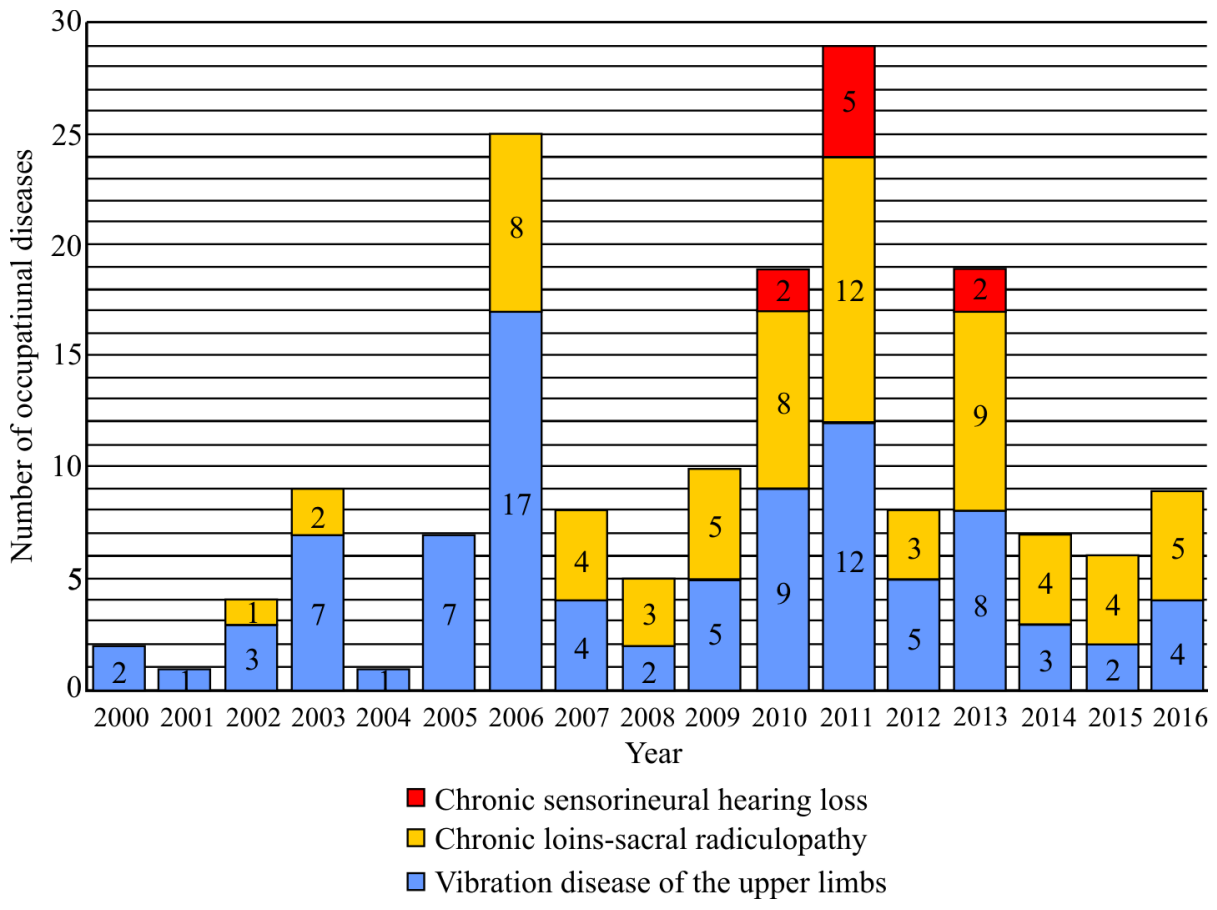

Fig. 4. Dynamics of the number of occupational diseases of underground personnel of the Yaregskoe oil mines for the period of 2000-2016

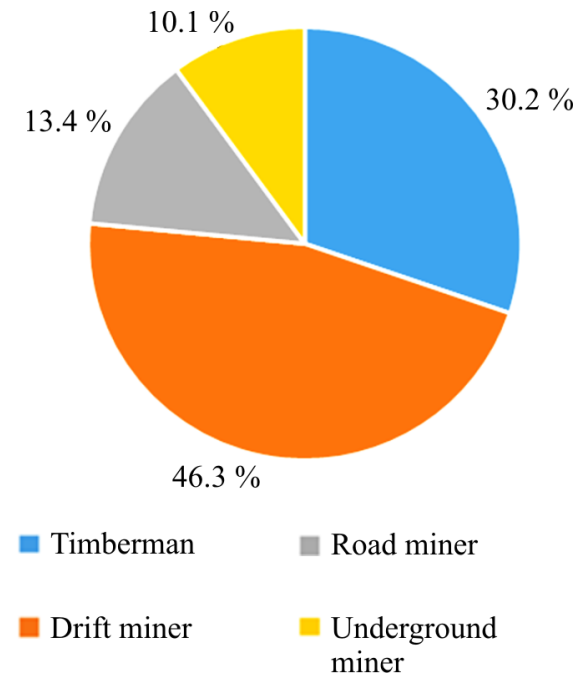

Fig. 5. Distribution of occupational diseases among persons by occupation in oil fields of the Yaregskoe field

The procedure for determination of prognostic occupational risks is based on use of materials from a special assessment of working conditions conducted in accordance with the methodology of a special assessment of working conditions according to Federal Law No. 426 of December 23, 2013, and attestation of workplaces held at the company before January 1, 2014 in accordance with the requirements of the "Procedure for the certification of workplaces for working conditions" approved by the order of the Ministry of Health and Social Development No. 342n of April 26, 2011 [29].

In order to assess the degree of compliance of the state of working conditions with normative requirements and degree to which the deviations from the normative values of labor conditions factors affect the human body, a system of special scores (usually six points) is used:

1 - optimal working conditions (class 1);

2 - allowable working conditions (class 2);

3 - not quite favorable working conditions (class 3.1);

4 - unfavorable working conditions (class 3.2);

5 - very unfavorable working conditions (class 3.3);

6 - ultra-extreme, critical working conditions (class 3.4).

The higher the score the greater the discrepancy between the working conditions for this factor and the more dangerous and harmful effects on the human body.

Such the methodology certainly gives positive results in determination of the influence of certain factors of the production environment on the state of human health. There are quite reliable mathematical models are constructed based on such the methodology for calculation of occupational risk, taking into account three main 
components such as level of the factor, duration of its impact and effective indicator, i.e. indicators of the health status of underground personnel.

The higher the score the greater the discrepancy between working conditions for that factor and the more dangerous and harmful its effect on the organism is.

The results of a quantitative assessment of the state of the production environment for individual factors with their isolated effects are shown in the Table 3.

Table 3

Calculated levels of safety of production factors at workplaces of underground personnel of the Yaregskoe oil mines for 2014-2016

\begin{tabular}{|c|c|c|c|c|c|c|c|c|c|c|c|}
\hline \multirow[b]{2}{*}{$\begin{array}{l}\text { Name of the } \\
\text { workplace }\end{array}$} & \multicolumn{10}{|c|}{ Levels of safety $S_{\mathrm{nc}}$ by the i-th production factor } & \multirow[b]{2}{*}{ Total safety level } \\
\hline & 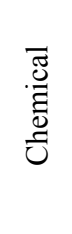 & $\underset{⿱ 亠 䒑}{2}$ & $\begin{array}{l}0 \\
\frac{0}{0} \\
z\end{array}$ & 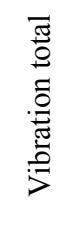 & 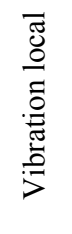 & 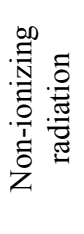 & 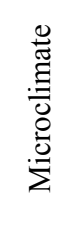 & 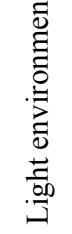 & 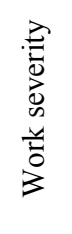 & 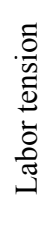 & \\
\hline Drift miner & 0.83 & 0.67 & 0.33 & 0.83 & 0.5 & - & 0.83 & - & 0.5 & - & 0.0316 \\
\hline $\begin{array}{l}\text { Machinist of mining } \\
\text { excavation machines }\end{array}$ & 0.83 & 0.33 & 0.5 & 0.67 & 0.67 & - & 0.83 & - & 0.83 & - & 0.0423 \\
\hline Timberman & 0.83 & 0.67 & 0.33 & 0.83 & 0.5 & - & 0.83 & - & 0.5 & - & 0.0316 \\
\hline Underground miner & 0.83 & 0.83 & 0.67 & 0.83 & - & - & 0.83 & - & 0.83 & - & 0.264 \\
\hline $\begin{array}{l}\text { Operator of oil and } \\
\text { gas production }\end{array}$ & 0.67 & 0.83 & 0.67 & 0.83 & - & - & 0.33 & - & 0.5 & - & 0.0510 \\
\hline $\begin{array}{l}\text { Underground } \\
\text { electrician }\end{array}$ & 0.83 & 0.83 & 0.67 & 0.83 & - & 0.83 & 0.83 & 0.83 & 0.83 & - & 0.182 \\
\hline Mechanic & 0.83 & 0.83 & 0.67 & 0.83 & - & - & 0.83 & 0.83 & 0.83 & - & 0.219 \\
\hline $\begin{array}{l}\text { Mining electric } \\
\text { locomotive driver }\end{array}$ & 0.83 & 0.83 & 0.67 & 0.83 & 0.83 & - & 0.83 & - & 0.83 & - & 0.219 \\
\hline Road miner & 0.83 & 0.83 & 0.83 & - & 0.83 & - & 0.83 & - & 0.67 & - & 0.264 \\
\hline Supervisor & 0.83 & 0.83 & 0.67 & 0.83 & - & - & 0.83 & 0.83 & 0.83 & - & 0.219 \\
\hline
\end{tabular}

As a scoring for the i-th unfavorable factor of the production environment the results of a special assessment of working conditions or attestation of workplaces on working conditions are used. Points are given in the following dependency on the class of working conditions [30]:
1.0 - 1 point;
$2.0-2$ points;
$3.1-3$ points;
$3.2-4$ points;
$3.3-5$ points;
$3.4-6$ points.

Assuming that all factors of the production environment operate independently of each other (additivity principle), estimation of the total risk level of $\mathrm{R}_{\mathrm{PE}}$ is [31]

$$
R_{\mathrm{PE}}=1-\prod_{i=1}^{n} S_{n c_{i}}
$$

where $n$ - number of environmental factors to be considered; $S_{n c_{i}}-$ the level of safety in the $i$-th factor of the production environment, which can be determined by the formula

$$
S_{n c_{i}}=\frac{\left(x_{\max }+1\right)-x_{i}}{x_{\max }}
$$

where $x_{\max }$ is for a maximum score, in accordance with the methodology of the Institute of Labor $x_{\max }=6$; $x_{i}$ is for score by $i$-th environment factor, calculated by the formulas in Table 1 or by the class of working conditions in accordance with P 2.2.2006-05.

It is important to note that the value determines the total level of safety of the production environment compared with work experience.

$$
S_{n c}=\prod_{i-1}^{n} S_{n c_{i}}
$$

Experience shows that the probability of disease in the time interval $t_{i}$ does not depend on whether the disease was in the previous period $t_{t-1}$, which indicates the independence of events. Then the probability of working without diseases (the level of safety of the working environment) 
for a period of $m$ years can be determined by the formula

$$
S_{n c}=\left(1-r_{\mathrm{a}}\right)^{m},
$$

where $r_{\mathrm{a}}$ is for annual professional risk. From (4), taking into account expression (3), we obtain

$$
r_{\mathrm{a}}=1-\sqrt[m]{\prod_{i-1}^{n} S_{n c}}
$$

where $m$ is for work experience ( 25 years).

The results of calculations according to the formula (5) should be close to the data obtained from the actual desease rates.
The results of the calculation of the level of safety for each workplace of underground personnel are presented in the Table 3 and Fig. 6 .

The results of calculations of the total level of safety (3), total level of risk (1) and annual professional risk (5) are grouped in the Table 4 and Fig. 7 for work places of underground personnel [32].

Calculated values of the level of occupational risk for each workplace of underground personnel should be compared with the maximum permissible risk for this workplace. This comparison is necessary for ranking risks that require prompt operational intervention, development of measures and adjustment of labor operations [33-35].

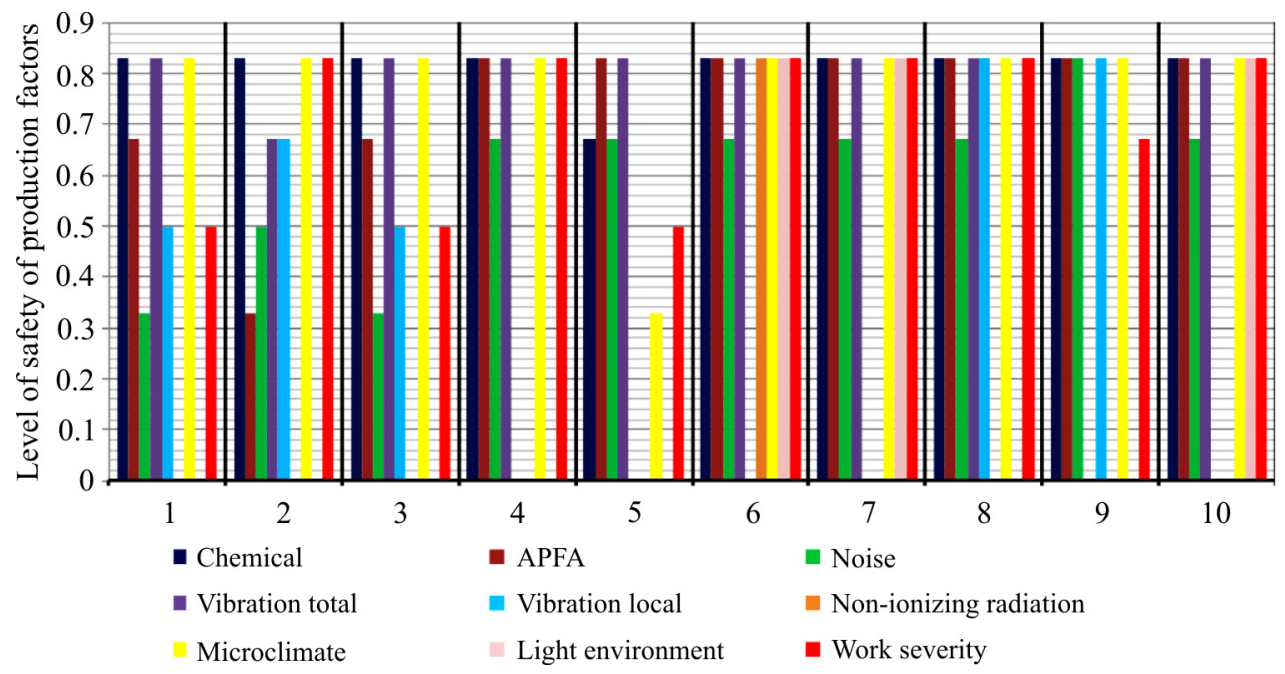

Fig. 6. Diagram of average values of safety levels of production factors of workplaces of the underground personnel of oil mines: 1 - drift miner; 2 - machinist of mining excavation machines; 3 -timberman; 4 - underground miner; 5 - operator of oil and gas production; 6 - underground electrician; 7 - mechanic; 8 - mining electric locomotive driver; 9 - road miner; 10 - supervisor

Table 4

Summary table of safety and risk of obtaining occupational disease by the underground personnel of the Yaregskoe oil mines for 2014-2016

\begin{tabular}{|l|c|c|c|c|}
\hline \multicolumn{1}{|c|}{ Name of the workplace } & $\begin{array}{c}\text { Total safety } \\
\text { level }\end{array}$ & Total risk level & $\begin{array}{c}\text { Maximum permissible } \\
\text { level of total risk }\end{array}$ & $\begin{array}{c}\text { Deviation of the actual level } \\
\text { of occupational risk from } \\
\text { the maximum allowable, } \%\end{array}$ \\
\hline Drift miner & 0.0316 & 0.968 & 0.82 & 18.04 \\
\hline $\begin{array}{l}\text { Machinist of mining excavation } \\
\text { machines }\end{array}$ & 0.0423 & 0.958 & 0.82 & 16.83 \\
\hline Timberman & 0.0316 & 0.968 & 0.82 & 18.05 \\
\hline Underground miner & 0.264 & 0.736 & 0.67 & 9.85 \\
\hline Operator of oil and gas production & 0.0510 & 0.949 & 0.82 & 45.73 \\
\hline Underground electrician & 0.182 & 0.818 & 0.78 & 6.99 \\
\hline Mechanic & 0.219 & 0.781 & 0.73 & 6.99 \\
\hline Mining electric locomotive driver & 0.219 & 0.781 & 0.73 & 9.85 \\
\hline Road miner & 0.264 & 0.736 & 0.67 & 6.99 \\
\hline Supervisor & 0.176 & 0.781 & 0.73 & \\
\hline
\end{tabular}



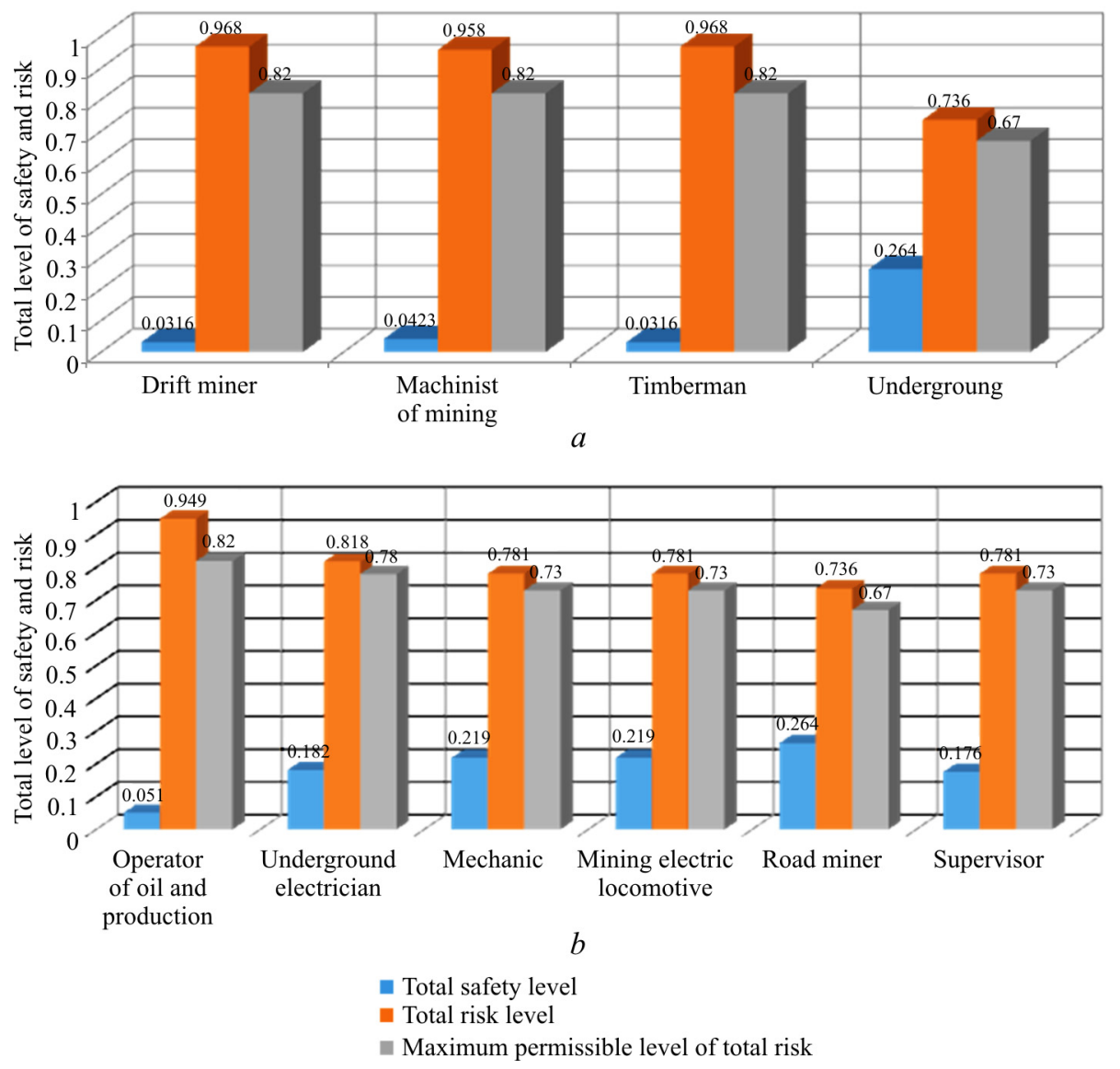

Fig. 7. Diagram of safety and risk of occupational disease:

$a$-personnel in the site of mine excavation and expansion of the Yaregskoe oil mines; $b$ - underground personnel of the Yaregskoe oil mines

The maximum permissible level of risk is calculated from the condition that all the factors of the working environment that act on the employee during labor activity are brought to the best level. Ideally, those factors are classes of working conditions for each factor 1.0 and 2.0, except for those that can not be reduced (improved) due to the peculiarities of the technological process (for example, noise from the equipment) [36].

If the level of exposure of the factor corresponds to the classes of working conditions 3.2, 3.3 and 3.4, but employees are equipped with certified personal protective equipment and regularly use them, and also organizational measures are taken to reduce the negative impact of the harmful factor, the class of working conditions can be estimated as less harmful (one step, but not lower than class 3.1) [37, 38].

In order to control the effectiveness of implemented measures to reduce the identified risk levels, the collective dose rate $\mathrm{J}$ of the adverse effects of labor conditions factors is calculated:

$$
J=\sum_{j=1}^{m} \sum_{i=1}^{n} x_{i j} \cdot N_{i j}
$$

where $m$ - number of workshops (sites) at the company; $n$ - the number of factors taken into account in working conditions in the workshop (site); $x_{i j}$ - score of the $i$-th factor of working conditions; $N_{i j}$ - number of employees under the influence of $i$-th factor.

The Table 5 shows an example of calculation of the collective dose capacity of the adverse impact of labor conditions factors on the underground staff of the Yaregskoe oil mines.

Collective dose rate of unfavorable expoisure of factors of working conditions in the company is $J=13805$ person-points. 
An example of calculation of the collective dose capacity of adverse effects of labor conditions factors in a company

\begin{tabular}{|c|c|c|c|}
\hline Workshop (group of workplaces) & $\begin{array}{l}\text { Identified dangerous } \\
\text { and harmful production factors }\end{array}$ & $\begin{array}{c}\text { Initial scores } \\
X_{i j}\end{array}$ & $\begin{array}{l}\text { Number of employees under } \\
\text { the influence of the } i j \text {-th dangerous } \\
\text { and harmful production factor }\end{array}$ \\
\hline \multirow{4}{*}{ Site of mine excavation and expansion } & Increased noise & 5 & 377 \\
\hline & Increased local vibration & 4 & 332 \\
\hline & Physical overload & 4 & 317 \\
\hline & Increased dustiness & 3 & 221 \\
\hline \multirow{5}{*}{$\begin{array}{l}\text { Brigade on mining of excavations by road header } \\
\text { machine KP- } 21\end{array}$} & Increased dustiness & 5 & 75 \\
\hline & Increased noise & 4 & 75 \\
\hline & Increased local vibration & 3 & 75 \\
\hline & Increased total vibration & 3 & 75 \\
\hline & Physical overload & 3 & 75 \\
\hline \multirow{2}{*}{$\begin{array}{l}\text { Site of repair and remedial works and intermine } \\
\text { transportation }\end{array}$} & Increased noise & 3 & 111 \\
\hline & Physical overload & 3 & 111 \\
\hline \multirow{4}{*}{ Oil production site } & Increased chemical factor & 3 & 372 \\
\hline & Increased noise & 4 & 372 \\
\hline & Increased temperature & 5 & 372 \\
\hline & Physical overload & 4 & 372 \\
\hline Site of underground electromechanical facilities & Increased noise & 3 & 102 \\
\hline Ventilation and safety site & Increased noise & 3 & 69 \\
\hline Mine raise site & Increased noise & 3 & 60 \\
\hline
\end{tabular}

\section{Conclusions}

Analytical review of working conditions of underground personnel allowed determining the main groups of negative factors such as noise, local and total vibration, microclimate and APFA, labor severity and chemical factor. The majority of workplaces in the Yaregskoe oil mines are mainly related to the class with harmful working conditions $(82 \%)$, i.e. activity carried on them can cause occupational diseases of personnel. Subclasses 3.1 and 3.3 correspond to a very high professional risk (45 and $33 \%$, respectively) and prevail. The main harmful and dangerous production factors allowed substantiating the causes of conditionality of certain forms of diseases in the work places of underground personnel of oil mines [18].

The analysis performed allowed to rank the probability of the impact of factors of a certain class of working conditions on personnel of the Yaregskoe oil mines by structural subdivisions.

However, during the survey of workplaces, there are difficulties in assessing the intensity of the work of the underground personnel of oil mines araise due to the absence of a rapid method for assessing the intensity of the labor process in the SEWC. That could shorten the time for assessing workplaces by working conditions. Therefore, that is necessary to develop and test new method.

There is a group of personnel in the risk for occupational pathology that consists of workers who are involved in the site of mine excavation and expansion. By the priority occupational diseases of the oil industry they are as follows: vibro-disease, chronic loins-sacral radiculopathy, chronic neurosensory hearing loss and the only case of reflex myotonic syndrome.

The analysis showed a high risk of getting occupational diseases by a group of underground personnel of the Yaregskoe oil mines. The persons at especially risk are as follows: drift miner, timberman, machinist of mining excavation machines, operator of oil and gas production. Workplaces of underground miner and road miner are the safest.

There is a high risk level observed in three parameters such as increased noise level, vibration and physical overload for the employees at the site of mine excavation and expansion.

\section{References}

1. Grunskoi T.V., Perkhutkin V.P., Berdnik A.G. Analiz i otsenka professional'nykh zabolevanii podzemnogo personala na nefteshakhtakh Iaregskogo mestorozhdeniia [Analysis and assessment of professional diseases of underground personnel on oil-stores of yaregsk place of birth]. Neftegazovoe delo, 2017, no.3, pp.128-144. DOI: 10.17122/ogbus-2017-3-128-144

2. Grunskoi T.V., Perkhutkin V.P. Upravlenie bezopasnost'iu trudovogo protsessa prokhodki gornykh vyrabotok v neftianykh shakhtakh Iaregskogo mestorozhdeniia 
[Management of the underground employment of safety mining in oil mines Yaregskaya field]. Resursy Evropeiskogo Severa. Tekhnologii i ekonomika osvoeniia, 2017, no.1, pp.10-22.

3. Grunskoi T.V., Perkhutkin V.P. Ustanovlenie vzaimosviazei uslovii truda s proizvodstvennymi protsessami pri intensifikatsii prokhodcheskikh rabot $\mathrm{v}$ neftianykh shakhtakh Iaregskogo mestorozhdeniia [Interconnection of working conditions with production processes when improving tunnel works in yaregskoye field oil mines]. Neftegazovoe delo, 2013, no.2, pp.184-193.

4. Grunskoi T.V., Perkhutkin V.P. Upravlenie bezopasnost'iu truda $\mathrm{v}$ usloviiakh intensifikatsii prokhodcheskikh rabot $\mathrm{v}$ neftianykh shakhtakh Iaregskogo mestorozhdeniia [Labour safety management in the context of intensified sinking operations at yaregskaya oil-field's mines]. Uchenye zapiski Komsomol'skogo-na-Amure gosudarstvennogo tekhnicheskogo universiteta, 2013, no.4, pp.101-109.

5. Grunskoi T.V., Perkhutkin V.P. Sovershenstvovanie informatsionnogo obespecheniia sistemy upravleniia bezopasnost'iu truda prokhodcheskikh rabot $\mathrm{V}$ nefteshakhtakh Iaregskogo mestorozhdeniia [Improvement of the information support of the work safety management system for tunnel work in the oil fields of the Yaregsky deposit]. Neftegazovoe delo, 2014, no.2, pp. 392-406. DOI: 10.17122/ogbus-2014-2-392-406

6. Grunskoi T.V., Perkhutkin V.P. Sovershenstvovanie metodologii otsenki uslovii truda pri intensifikatsii prokhodcheskikh rabot $\mathrm{V}$ neftianykh shakhtakh Iaregskogo mestorozhdeniia [Improvement of the methodology for assessing working conditions in the intensification of tunneling works in the oil mines of the Yaregsky deposit]. Promyshlennaia bezopasnost' mineral'no-syr'evogo kompleksa $v$ XXI veke. Gornyi informatsionno-analiticheskii biulleten' (nauchnotekhnicheskii zhurnal), 2015, no.2, special iss.7,816 p.

7. Nor E.V. Prognoznaia otsenka pylegazovogo rezhima vozdukha rabochikh zon neftianykh shakht pri parateplovom vozdeistvii na plast (na primere Iaregskogo mestorozhdeniia vysokoviazkoi nefti) [Forecast estimation of dust-gas regime of air in working zones of oil mines with paratermal influence on the formation (on the example of Yaregsky field of high-viscosity oil)]. Ph. D. thesis. Ukhta, 2004, 130 p.

8. Novikov S.M. Otsenka riska dlia zdorov'ia. Algoritm rascheta doz pri otsenke riska, obuslovlennogo mnogosredovymi vozdeistviiami khimicheskikh veshchestv [Health risk assessment. The algorithm for calculating doses in assessing the risk caused by multisecret exposures of chemicals]. Moscow, 1999, $51 \mathrm{p}$.

9. Novikov S.M., Avaliani S.L., Bushtueva K.A. Otsenka riska dlia zdorov'ia. Opyt primeneniia metodologii otsenki riska $\mathrm{v}$ Rossii [Health risk assessment. Experience in applying the methodology of risk assessment in Russia]. Moscow, 1999, 290 p.

10. Analiz i upravlenie riskom: teoriia i praktika [Risk analysis and management: theory and practice]. Moscow, Strakhovaia gruppa "LUKOIL", 2016, 186 p.

11. Izmerov N.F., Denisov E.I., Molodkina N.N. et al. Metodologiia otsenki professional'nogo riska $\mathrm{v}$ meditsine truda [Methodology for assessing occupational risk in occupational medicine]. Meditsina truda i promyshlennaia ekologiia, 2001, no.12, pp.1-7.

12. Khasanova A.A., Shur P.Z., Shliapnikov D.M. Otsenka izmenenii funktsii organizma pod vliianiem uslovii professional'noi deiatel'nosti [Assessment of changes in body functions under the influence of professional conditions]. Vestnik Permskogo universiteta, 2014, iss.2, pp.48-51.

13. Gladkova L.A., Zuev B.Iu., Istomin R.S., Loginov M.A. Analiz sovremennykh metodov i sredstv monitoringa pri podzemnoi razrabotke poleznykh iskopaemykh [Analysis of modern methods and means of monitoring for underground mining of minerals]. Gornyi informatsionnoanaliticheskii biulleten', 2010, no.4, pp.19-24.

14. Khenli D., Kumamoto Kh. Nadezhnost' tekhnicheskikh sistem i otsenka riska [Reliability of technical systems and risk assessment]. Moscow, Mashinostroenie, 1984, $528 \mathrm{p}$.

15. Elokhin A.N. Analiz i upravlenie riskom: teoriia i praktika [Risk analysis and management: theory and practice]. Moscow, Strakhovaia gruppa "LUKOIL", 2010, 186 p.

16. Malyshev D.V. Analiz sistem upravleniia promyshlennoi bezopasnost'iu, okhranoi truda $\mathrm{V}$ RF i zarubezhnykh neftegazovykh kompaniiakh [Analysis of industrial safety management systems, labor protection in the Russian Federation and foreign oil and gas companies]. Aktual'nye problemy sostoianiia $i$ razvitiia neftegazovogo kompleksa Rossii. Tezisy doklada 5 nauchno-tekhnicheskoi konferentsii. Moscow, Rossiiskii gosudarstvennyi universitet nefti i gaza im. I.M. Gubkina, 2003, p.6.

17. Gorskaia T.V. Otsenka uslovii truda v metallurgii s uchetom sochetannogo vozdeistviia vrednykh proizvodstvennykh faktorov [Assessment of working conditions in metallurgy, taking into account the combined effect of harmful production factors]. Ph. D. Thesis. Moscow, 2007, 148 p.

18. Doliatovskii V.A., Doliatovskaia V.N. Issledovanie sistem upravleniia [Research of management systems]. Moscow, Mart, 2003, 256 p.

19. Mukminov R.A., Galliamov M.A. Matematicheskoe modelirovanie protsessov okhrany truda [Mathematical modeling of labor protection processes]. Ufa, Ufimskii neftianoi institut, 1990, 74 p.

20. Serbinovskii B.Iu., Rudik E.V. Monitoring proizvoditel'nosti truda [Monitoring of labor productivity]. Novocherkassk, LIK, 2010, 260 p.

21. Iang S. Sistemnoe upravlenie organizatsiei [System management of the organization]. Eds. S.P. Nikonorov, S.A. Batasov. Moscow, Sovetskoe radio, 1972, 456 p.

22. Ust'iantsev S.L., Smirnov E.A. Gigienicheskaia otsenka faktorov trudovogo protsessa operatorov avtozapravochnykh stantsii [Hygienic assessment of factors in the labor process of operators of gas stations]. Gigiena i sanitariia, 2007, no.10, pp.34-38

23. $\mathrm{R}$ 2.2.1766-03. Rukovodstvo po otsenke professional'nogo riska dlia zdorov'ia rabotnikov. Organizatsionno-metodicheskie osnovy, printsipy i kriterii otsenki [Guidance on the assessment of occupational health risks for workers. Organizational-methodical bases, principles and criteria of evaluation]. Eds. N.F. Izmerov, E.I. Denisov. Moscow, Trovant, 2003, 448 p.

24. R 2.2.2006-05. Rukovodstvo po gigienicheskoi otsenke faktorov rabochei sredy i trudovogo protsessa. Kriterii i klassifikatsiia uslovii truda [Guidance on hygienic assessment of working environment factors and the work process. Criteria and classification of working conditions]. Eds. N.F. Izmerov et al. 
Moscow, Nauchno-issledovatel'skii institut meditsiny truda imeni akademika N.F. Izmerova, 2005, 130 p.

25. Timofeeva S.S. Metody i tekhnologii otsenki proizvodstvennykh riskov: prakticheskie raboty dlia magistrantov po napravleniiu 280700 “Tekhnosfernaia bezopasnost"' [Methods and technologies for assessing production risks: practical work for undergraduates in the direction 280700 "Technospheric Security"]. Irkutsk, Izdatel'stvo Irkutskogo gosudarstvennogo tekhnicheskogo universiteta, 2014, $177 \mathrm{p}$

26. Practical tools and checklists for risk assessment. Prilozhenie 1. Instrument otsenki riskov. Evropeiskoe Agentstvo po obespecheniiu zdorov'ia i bezopasnosti rabotnikov. Bil'bao, Ispaniia, 2007.

27. Principles for the assessment of risks to human health from exposure to chemicals Environmental Health Criteria 210, Geneva, WHO, 1999, available at: http://www.inchem.org/ documents/ehc/ehc/ehc210.htm (accessed: 12 April 2017).

28. Sources, effects and risk of ionizing radiation. Report. United Nations Scientific Committee on the Effects of Atomic Radiation (UNSCEAR), 2000, 659 p., available at: http://www.unscear.org/docs/publications/2000/UNSCEAR_200 0_Report_Vol.I.pdf(accessed: 12 April 2017).

29. Regulations approved code of practice, health and safety executive / Managing health and safety in construction (Design and Management), London, 2007, $452 \mathrm{p}$.

30. Reese C.D., Eidson J.V. Handbook of OSHA construction safety and health. Taylor \& Francis Group, LLC, 2006, 483 p.

31. Salminen S. Have young workers more injuries than older ones? An international literature review.
Journal of Safety Research, 2011, vol.35, iss.5, pp.513521. DOI: $10.1016 /$ j.jsr.2004.08.005

32. Kines P. Construction workers' falls through roofs: Fatal versus serious injuries. Journal of Safety Research, 2002, vol.33(2), pp.195-208. DOI: 10.1016/S0022-4375(02)00019-1

33. Holte K.A., Kjestveit K., Lipscomb H.J. Company size and differences in injury prevalence among apprentices in building and construction in Norway. Safety Science, 2015, vol.71, part C, pp.205-212. DOI: 10.1016/j.ssci.2014.01.007

34. Kim S., Nussbaum M.A., Jia B. The benefits of an additional worker are task-dependent: Assessing low-back injury risks during prefabricated (panelized) wall construction. Applied Ergonomics, 2012, vol.43(5), pp.843-849. DOI: 10.1016/j.apergo.2011.12.005

35. Kostić R., Vatin N., Murgul V. Fire safeguards of "Plastbau" construction. Applied Mechanics and Materials, 2015, vol.725-726, 145 p. DOI: 10.4028/www.scientific.net/AMM.725-726.138

36. Salehi S.H., Fatemi M.J., Aśadi K., Shoar S., Ghazarian A., Samim, R. Electrical injury in construction workers: a special focus on injury with electrical power. Burns, 2014, vol.40(2), pp. 300-304. DOI: 10.1016/j.burns.2013.05.019

37. Spangenberg S., Baarts Ch., Dyreborg J., Jensen L., Kines P., Mikkelsen K.L. Factors contributing to the differences in work related injury rates between Danish and Swedish construction workers. Safety Science, 2003, vol.41(6), pp.517530. DOI: 10.1016/S0925-7535(02)00007-3

38. Vatin N., Gamayunova O., Petrosova D. Relevance of education in construction safety area. Applied Mechanics and Materials, 2014, 635-637, 2089 p. DOI: 10.4028/www.scientific.net/AMM.635-637.2085

\section{Библиографический список}

1. Грунской Т.В., Перхуткин В.П., Бердник А.Г. Анализ и оценка профессиональных заболеваний подземного персонала на нефтешахтах Ярегского месторождения // Нефтегазовое дело. - 2017. - № 3. C. 128-144. DOI: 10.17122/ogbus-2017-3-128-144

2. Грунской Т.В., Перхуткин В.П. Управление безопасностью трудового процесса проходки горных выработок в нефтяных шахтах Ярегского месторождения // Ресурсы Европейского Севера. Технологии и экономика освоения. -2017 . - № 1. - С. 10-22.

3. Грунской Т.В., Перхуткин В.П. Установление взаимосвязей условий труда с производственными процессами при интенсификации проходческих работ в нефтяных шахтах Ярегского месторождения // Нефтегазовое дело. - 2013. - № 2. - С. 184-193.

4. Грунской Т.В., Перхуткин В.П. Управление безопасностью труда в условиях интенсификации проходческих работ в нефтяных шахтах Ярегского месторождения // Ученые записки Комсомольскогона-Амуре гос. техн. ун-та. - 2013. - № 4. - С. 101-109.

5. Грунской Т.В., Перхуткин В.П. Совершенствование информационного обеспечения системы управления безопасностью труда проходческих работ в нефтешахтах Ярегского месторождения // Нефтегазовое дело. - 2014. № 2. - C. 392-406. DOI: 10.17122/ogbus-2014-2-392-406.

6. Грунской Т.В., Перхуткин В.П. Совершенствование методологии оценки условий труда при интенсификации проходческих работ в нефтяных шахтах Ярегского месторождения // Промышленная безопасность минеральносырьевого комплекса в XXI веке: горный информационноаналитический бюллетень (научно-технический журнал). М.: Горная книга, 2015. - № 2, спец. вып. 7. -816 с.

7. Нор Е.В. Прогнозная оценка пылегазового режима воздуха рабочих зон нефтяных шахт при паратепловом воздействии на пласт (на примере Ярегского месторождения высоковязкой нефти): дис. ... канд. техн. наук. - Ухта, 2004. - 130 с.

8. Новиков С.М. Оценка риска для здоровья. Алгоритм расчета доз при оценке риска, обусловленного многосредовыми воздействиями химических веществ. - М., 1999. - 51 с.

9. Новиков С.М., Авалиани С.Л., Буштуева К.А. Оценка риска для здоровья. Опыт применения методологии оценки риска в России. - М., 1999. - 290 с.

10. Анализ и управление риском: теория и практика / Страховая группа «ЛУКОЙЛ». - М., 2016. - 186 с.

11. Методология оценки профессионального риска в медицине труда / Н.Ф. Измеров, Э.И. Денисов, Н.Н. Молодкина [и др.] // Медицина труда и промышленная экология. - 2001. - № 12. - С. 1-7.

12. Хасанова А.А., Шур П.З., Шляпников Д.М. Оценка изменений функций организма под влиянием условий профессиональной деятельности // Вестник Пермского университета. - 2014. - Вып. 2. - С. 48-51.

13. Анализ современных методов и средств мониторинга при подземной разработке полезных 
ископаемых / Л.А. Гладкова, Б.Ю. Зуев, Р.С. Истомин, М.А. Логинов // Горный информационно-аналитический бюллетень. - 2010. - № 4. - С. 19-24.

14. Хенли Д., Кумамото Х. Надежность технических систем и оценка риска: пер. с англ. - М.: Машиностроение, 1984. - 528 с.

15. Елохин А.Н. Анализ и управление риском: теория и практика / Страховая группа «ЛУКОЙЛ». M., 2010. - $186 \mathrm{c}$.

16. Малышев Д.В. Анализ систем управления промышленной безопасностью, охраной труда в РФ и зарубежных нефтегазовых компаниях // Актуальные проблемы состояния и развития нефтегазового комплекса России: тез. докл. 5-й науч.-техн. конф. / Рос. гос. ун-т нефти и газа им. И.М. Губкина - М., 2003. - C. 6.

17. Горская Т.В. Оценка условий труда в металлургии с учетом сочетанного воздействия вредных производственных факторов: дис. ... канд. техн. наук: 05.26.01. - М., 2007. - 148 с.

18. Долятовский В.А., Долятовская В.Н. Исследование систем управления. - М.: Март, 2003. - 256 с.

19. Мукминов Р.А., Галлямов М.А. Математическое моделирование процессов охраны труда: учеб. пособие. - Уфа: Изд-во Уфим. нефт. ин-та, 1990. - 74 c.

20. Сербиновский Б.Ю., Рудик Е.В. Мониторинг производительности труда. - Новочеркасск: ЛИК, 2010. $-260 \mathrm{c}$.

21. Янг С. Системное управление организацией / пер. с англ. под ред. С.П. Никонорова, С.А. Батасова. М.: Сов. радио, 1972. -456 с.

22. Устьянцев С.Л., Смирнов Е.А. Гигиеническая оценка факторов трудового процесса операторов автозаправочных станций // Гигиена и санитария. 2007. - № 10. - C. 34-38

23. Р 2.2.1766-03. Руководство по оценке профессионального риска для здоровья работников. Организационно-методические основы, принципы и критерии оценки / под ред. Н.Ф. Измерова, Э.И. Денисова. М.: Тровант, 2003. -448 с.

24. Р 2.2.2006-05. Руководство по гигиенической оценке факторов рабочей среды и трудового процесса. Критерии и классификация условий труда / под ред. Н.Ф. Измерова [и др.]; ГУ НИИ медицины труда PAMMH. - М., 2005. - $130 \mathrm{c}$.

25. Тимофеева С.С. Методы и технологии оценки производственных рисков: практические работы для магистрантов по направлению 280700 «Техносферная безопасность». - Иркутск: Изд-во Иркутск. гос. техн. ун-та, 2014. - 177 c.

26. Practical tools and checklists for risk assessment. Приложение 1. Инструмент оценки рисков /
Европейское Агентство по обеспечению здоровья и безопасности работников. - Бильбао, 2007.

27. Principles for the assessment of risks to human health from exposure to chemicals [Электронный pecypc] // Environmental Health Criteria 210. - Geneva: WHO, 1999. URL: http://www.inchem.org/documents/ehc/ehc/ehc210.htm (дата обращения: 12.04.2017).

28. Sources, effects and risk of ionizing radiation: report [Электронный ресурс] / United Nations Scientific Committee on the Effects of Atomic Radiation (UNSCEAR), 2000. - URL: http://www.unscear.org/docs/ publications/2000/UNSCEAR_2000_Report_Vol.I.pdf (дата обращения: 12.04.2017).

29. Regulations approved code of practice, health and safety executive. Managing health and safety in construction (Design and Management). - London, 2007. - 452 p.

30. Reese C.D., Eidson J.V. Handbook of OSHA construction safety and health. - Taylor \& Francis Group, LLC, 2006. - $483 \mathrm{p}$.

31. Salminen S. Have young workers more injuries than older ones? An international literature review // Journal of Safety Research. - 2004. - Vol. 35, iss. 5. P. 513-521. DOI: $10.1016 /$ j.jsr.2004.08.005

32. Kines P. Construction workers' falls through roofs: fatal versus serious injuries // Journal of Safety Research. - 2002. Vol. 33(2). - P. 195-208. DOI: 10.1016/S0022-4375(02)00019-1

33. Holte K.A., Kjestveit K., Lipscomb H.J. Company size and differences in injury prevalence among apprentices in building and construction in Norway // Safety Science. - 2015. - Vol. 71, part C. - P. 205-212. DOI: $10.1016 /$ j.ssci.2014.01.007

34. Kim S., Nussbaum M.A., Jia B. The benefits of an additional worker are task-dependent: assessing low-back injury risks during prefabricated (panelized) wall construction // Applied Ergonomics. - 2012. - Vol. 43(5). P. 843-849. DOI: 10.1016/j.apergo.2011.12.005

35. Kostić R., Vatin N., Murgul V. Fire safeguards of "Plastbau" construction // Applied Mechanics and Materials. - 2015. - Vols. 725-726. - 145 p. DOI: 10.4028/www.scientific.net/AMM.725-726.138

36. Electrical injury in construction workers: A special focus on injury with electrical power / S.H. Salehi, M.J. Fatemi, K. Aśadi, S. Shoar, A. Ghazarian, R. Samimi // Burns. - 2014. Vol. 40(2). - P. 300-304. DOI: 10.1016/j.burns.2013.05.019

37. Factors contributing to the differences in work related injury rates between Danish and Swedish construction workers / S. Spangenberg, Ch. Baarts, J. Dyreborg, L. Jensen, P. Kines, K.L. Mikkelsen // Safety Science. - 2003. - Vol. 41(6). - P. 517530. DOI: 10.1016/S0925-7535(02)00007-3

38. Vatin N., Gamayunova O., Petrosova D. Relevance of education in construction safety area // Applied Mechanics and Materials. - 2014. - 635-637. - 2089 p. DOI: 10.4028/www.scientific.net/AMM.635-637.2085

Please cite this article in English as:

Grunskoy T.V., Perkhutkin V.P., Berdnik A.G. Analytical review of working conditions of underground personnel in the oil mines of the Yaregskoe field. Perm Journal of Petroleum and Mining Engineering, 2017, vol.16, no.4, pp.378-390. DOI: 10.15593/2224-9923/2017.4.9

Просьба ссылаться на эту статью в русскоязычных источниках следующим образом:

Грунской Т.В., Перхуткин В.П., Бердник А.Г. Аналитический обзор условий труда подземного персонала нефтяных шахт Ярегского месторождения // Вестник Пермского национального исследовательского политехнического университета. Геология. Нефтегазовое и горное дело. - 2017. - Т.16, №4. - С.378-390. DOI: 10.15593/2224-9923/2017.4.9 